\title{
DETECTION OF MICROORGANISMS (BACTERIA, FUNGI AND YEASTS) IN ROYAL JELLY
}

\author{
Zeinab, A. Ashour ${ }^{1 *}$; Ali ${ }^{1}$ M.A.M., Sawsan M. Abdelmegeed ${ }^{1}$ and Amin $^{2}$ K.M.
}

1- Plant Protection Dept., Fac. of Agric., Ain Shams Univ., P.O. Box 68, Hadayek Shobra 11241, Cairo, Egypt

2- Agric., Biochemistry Dept., Fac. of Agric., Ain Shams Univ., P.O. Box 68, Hadayek Shobra 11241, Cairo, Egypt

*Corresponding author: zozomoon1991@yahoo.com

Received 29 July, 2018

Accepted 30 September, 2018

\section{ABSTRACT}

The aim of the present study to detect the population and frequency (\%) of microorganism (bacteria, fungi and yeasts) in royal jelly samples. The data indicated that, there are no significant differences were remarked in the population of microorganisms between all the samples for bacteria, fungi and yeasts, where the mean number of population was $5.923,1.38$ and 7.85 colonies/sample for bacteria, fungi and yeasts respectively, in produced royal jelly from honeybee colonies, local royal jelly collected from Egyptian market and samples of imported royal jelly collected from Egyptian market, respectively. According to the isolation and identification procedures for detected royal jelly samples, four bacteria types (Clostridium botulinum, Bacillus cereus, Bacillus wakoensis and Micrococcus luteus), two fungi types (Aspergillusniger and Penicillium sp.) and one yeast type (Saccharomyces cerevisiae) were determined. The data also summarized that Clostridium botulinum was the most frequency compared with the other bacterial types, where the percentage of frequency was $1.8-2.5,0.9-1.4,0.4-0.6$ and $1.5-2.0 \%$ for C. botulinum, B. cereus, B. wakoensis and $\mathrm{Mi}$ crococcus luteus, respectively. Meanwhile, Penicillium sp. the most frequency compared with $A$. niger, where the percentage of frequency was 0.5 2.9 and $0.7-1.0 \%$, respectively, in produced royal jelly from honeybee colonies, local royal jelly samples collected from Egyptian market and imported royal jelly samples collected from Egyptian market respectively. Regarding the yeasts, the data also summarized that, $S$. cerevisiae was the most frequency in royal jelly that produced from honeybee colonies (2.9\%) followed by which local royal jelly samples collected from Egyptian market (2.1\%) and imported royal jelly samples collected from Egyptian market (1.8\%).

Keywords: Royal jelly, Microorganisms, Bacteria, Fungi, Yeasts

\section{INTRODUCTION}

The royal Jelly $(R J)$ is a yellowish-white, creamy, acidic secretion, with a slightly strong scent and taste produced by honeybees. It is the fundamental food of queen honeybees and is secreted from the mandibular glands and hypopharingeal of worker bees (Fujiwara et al (1990). RJ is rich in carbohydrates, proteins, vitamins and minerals (Lercker et al 1982 and Palma, 1992) and stored in the nest, under field conditions. RJ is extremely vulnerable in its resistance to colonization by microorganisms (e.g. bacteria and yeasts) associated to bee hive products (Fujiwara et al 1990).

A lot of previous studies showed a broad range of medical activities in royal jelly, for example: antimicrobial effects (Weston et al 2000 and Lees and Shojaee Aliabadi, 2002), suppression of allergic responses (Leung et al 1997; Lombardi et al 1998 and Oka, 2001), lowering the amount of blood cholesterol (Shen et al 1995 and Vittek, 1995), preventing cell damage in cancer and HIV patients (Manfredi and Chiodo, 2000 and Takahashi et al 2001), as well as wound healing and growth acceleration (Fujii et al 1990).

The inhibitory activity of RJ against both Gram positive and Gram-negative bacteria has been demonstrated for many years (McCleskey and 
Melampy, 1938). The effectiveness of antibacterial properties of $\mathrm{RJ}$ could be related to a specific fatty acid present in ether-soluble fraction of royal jelly called trans-10-hydroxy decenoic acid (Blum et al 1959; Kitahara et al 1995 and Genc, and Aslan, 1999). The contents of 10-HDA, a bioactive component of royal jelly, and several vitamins did not change during storage at $40^{\circ} \mathrm{C}$ for 7 days. The substance has the chemical formula of (C10 H8 O3) and occupies $10 \%$ of the total weight of RJ (Budavari et al 1996; Genc and Aslan, 1999 and Parfitt, 1999).

Fontana et al (2004) isolated and characterized four antimicrobial peptides from RJ of honeybees. The Jelleines, a series of short peptides presenting a wide-spectrum of activity against each of Gram-positive and negative bacteria, and against yeasts. Inhibitory effect was shown for the peptide fraction against the honeybee pathogen Paenibacillus larvae larvae, which is the primary pathogen of American foulbrood disease, also against other Gram-positive bacteria such as Bacillus subtilis and Sarcinalutea Bilikova, et al (2001). Moreover, antifungal effect was shown also for the peptide fraction. The antibiotic polypeptide Royalisin, 51 amino acid residues, providing protection against infection of RJ by Gram-positive bacteria at low concentrations, but not against Gram-negative bacteria. Royal is in may be implicated in the active defense system against bacterial invasion of the honeybee (Fujiwara et al 1990).

The objective of the current research is to detect the number of population and the frequency of microorganisms (bacteria, fungi and yeasts) in locally produced and imported royal jelly.

\section{MATERIALS AND METHODS}

\section{Royal jelly samples}

Fifteen royal jelly samples were collected from different sources to study the microorganism's content (bacteria, fungi and yeasts). Five royal jelly samples produced from honey bee colonies, five royal jelly samples collected from Egyptian local market and five samples of imported royal jelly were collected from Egyptian market. Each sample was collected in clean-dark plastic cup and stored in deep freezer until isolation of microorganisms.

\section{Isolation and population of microorganisms in} royal jelly samples

Nutrient agar (NA), water agar (WA) and nutrient yeast extract dextrose agar (NYDA) media were used to isolation and develop for bacteria, fungi and yeasts population, respectively. Royal jelly suspension was prepared by adding ten $\mathrm{g}$ of royal jelly to flask contained $90 \mathrm{ml}$ of sterilized distilled water and was shaken at $1000 \mathrm{rpm}$ for $2 \mathrm{hr}$. One $\mathrm{ml}$ of the prepared solutions was added onto sterilized petri dish and about $20 \mathrm{ml}$ of previously method specific agar media $\left(45-50^{\circ} \mathrm{C}\right)$ were added to it (Mehrotra et al 1996; Barnett and Hunter 1987 and Fahy and Persley 1983). Four plates were used as replicates for each treatment. After gentle rotation, inoculated plates were incubated at $28^{\circ} \mathrm{C}$ for $2-5$ days. Number of bacteria, fungi and yeasts colonies were counted and recorded per sample to calculate their population. Single colonies were picked up and transferred to another slant media. Obtained bacteria, fungi and yeasts isolates were kept in a refrigerator for further studies.

\section{Identification of microorganisms in royal jelly samples}

Selected colonies of bacteria, fungi and yeasts were transferred to sterilized petri dishes contained previous specific medium for purification by streaked plate technique and incubated at $28^{\circ} \mathrm{C}$ for 2.5 days. According to cultural, morphological and physiological characters, selected bacteria (Schaad, 1980 and Bochner, 1991), fungi (Barnett and Hunter, 1987); and yeasts (Kreger-Van Rij, 1984; Odds, 1988 and Barnett et al 2000) were kindly identified in the microbiology center, Faculty of Science, Al-Azhar University, Cairo, Egypt.

\section{Statistical analysis}

Obtained data were statistically analyzed by using a randomized complete block design in factorial arrangement according to Sndecor and Cocheran (1990). For separation between means, least significant difference at $5 \%$ probability was applied.

\section{RESULTS AND DISCUSSION}

The population and frequency of microorganisms (\%) in royal jelly produced from honeybee colonies, local royal jelly samples collected from Egyptian market and imported royal jelly collected from Egyptian market samples is illustrated in Fig. 1, 2, 3 and 4. 
4-5-1- Population of microorganisms in royal jelly samples

As shown in Fig. (1) The population of bacteria was $4.60,10.67$ and 4.40 colony/sample for bacteria $1.20,2.33$ and 1.00 colony/sample for fungi $5.47,7.00$ and 3.47 colony/sample for yeast, in royal jelly produced from honeybee colonies, local royal jelly samples collected from Egyptian market and imported royal jelly samples collected from Egyptian market, respectively.

No significant differences were found between all the samples in population of bacteria, fungi and yeasts. The data also summarized that fungi were the least population in all the royal jelly samples when compared with bacteria and yeasts.

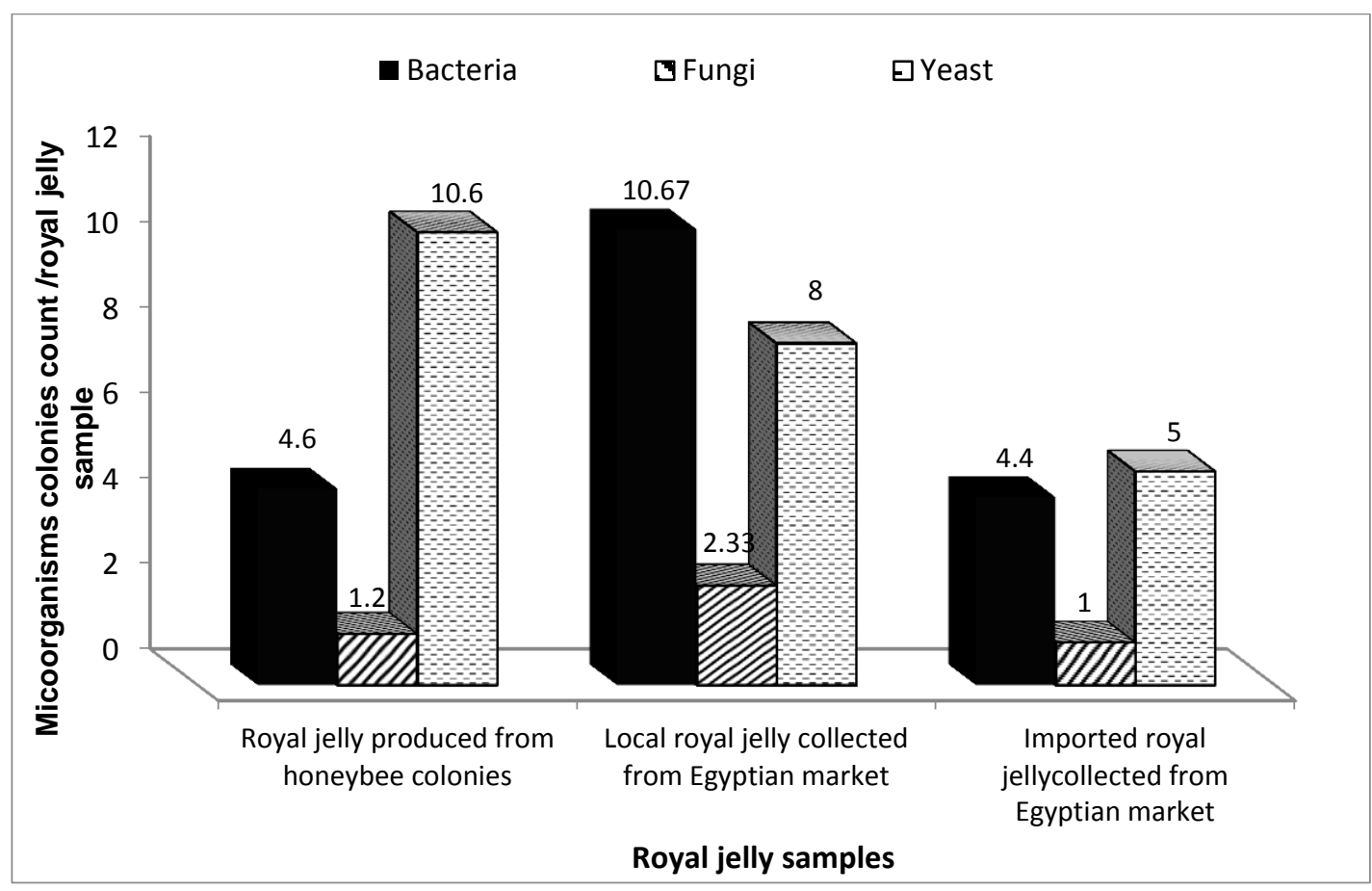

Fig. 1. Population numbers of bacteria, fungi and yeasts in royal jelly samples produced from honeybee colonies, local royal jelly samples collected from Egyptian market and imported royal jelly samples collected from Egyptian market.

Frequency (\%) of microorganisms (bacteria,
fungi and yeasts) in royal jelly samples

The frequency (\%) of bacteria, fungi and yeasts for royal jelly produced from honeybee colonies, local royal jelly samples collected from Egyptian market and imported royal jelly collected from Egyptian market samples collected from Egyptian market is illustrated in Fig. 2, 3 and 4. According to isolation and identification procedures, four bacteria types (Clostridium botulinum, Bacillus cereus, Bacillus wakoensis and Micrococcus luteus), two fungi types (Aspergillus niger and Penicillium spp) and one yeasts types (Saccharomyces cerevisiae) were determined according to cultural, morpholog- ical and physiological characters. The frequency (\%) of $C$. botulinum was $2.3,2.5$ and $1.8, B$. cereus was $1.3,1.4$ and $0.9, B$. wakoensiswas $0.4,0.6$ and 0.5 and Micrococcus luteuswas 1.8, 2.0 and $1.5 \%$ for royal jelly produced from honeybee colonies, local royal jelly samples collected from Egyptian market and imported royal jelly samples collected from Egyptian market samples, respectively.

The data also summarized that Clostridium botulinum was the most frequency compared with other bacteria types, where the average of frequency was $1.8-2.5,0.9-1.4,0.4-0.6$ and 1.5 - $2.0 \%$ for C. botulinum, B. cereus, B.wakoensis and Micrococcus luteus, respectively (Fig. 2). 
For fungi; the percentage of frequency for $A$. niger was $0.6,0.9$ and 0.5 and Penicilliumsp. was $(0.8,1.0$ and 0.7$)$ for royal jelly produced from honeybee colonies, local royal jelly samples collected from Egyptian market and imported royal jelly samples collected from Egyptian market, respectively. Meanwhile, Penicilliumsp.fungus was the most frequency compared with $A$. niger, where the average of frequency was $0.5-2.9$ and $0.7-$ $1.0 \%$, respectively (Fig. 3 ).
Regarding the yeasts, the percentage of frequency for Saccharomyces cerevisiae was 2.9, 2.1 and $1.8 \%$ for royal jelly produced from honeybee colonies, local royal jelly collected from Egyptian market and imported royal jelly samples collected from Egyptian market, respectively. The data also summarized that the $S$. cerevisiae was the most frequency in royal jelly produced from honeybee colonies followed by local royal jelly samples collected from Egyptian market and imported royal jelly samples collected from Egyptian market, respectively (Fig. 4).

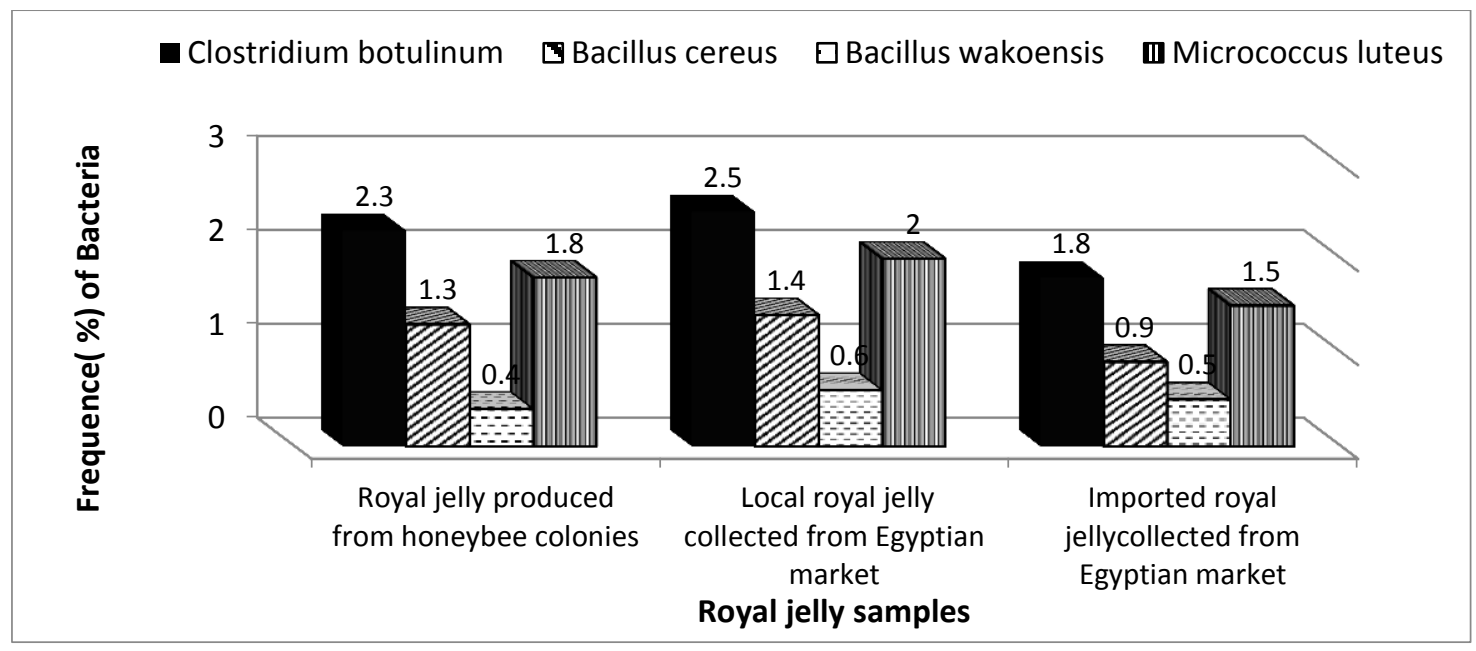

Fig. 2. Frequency (\%) of bacteria in royal jelly samples produced from honeybee colonies, local royal jelly samples collected from Egyptian market and imported royal jelly samples collected from Egyptian market

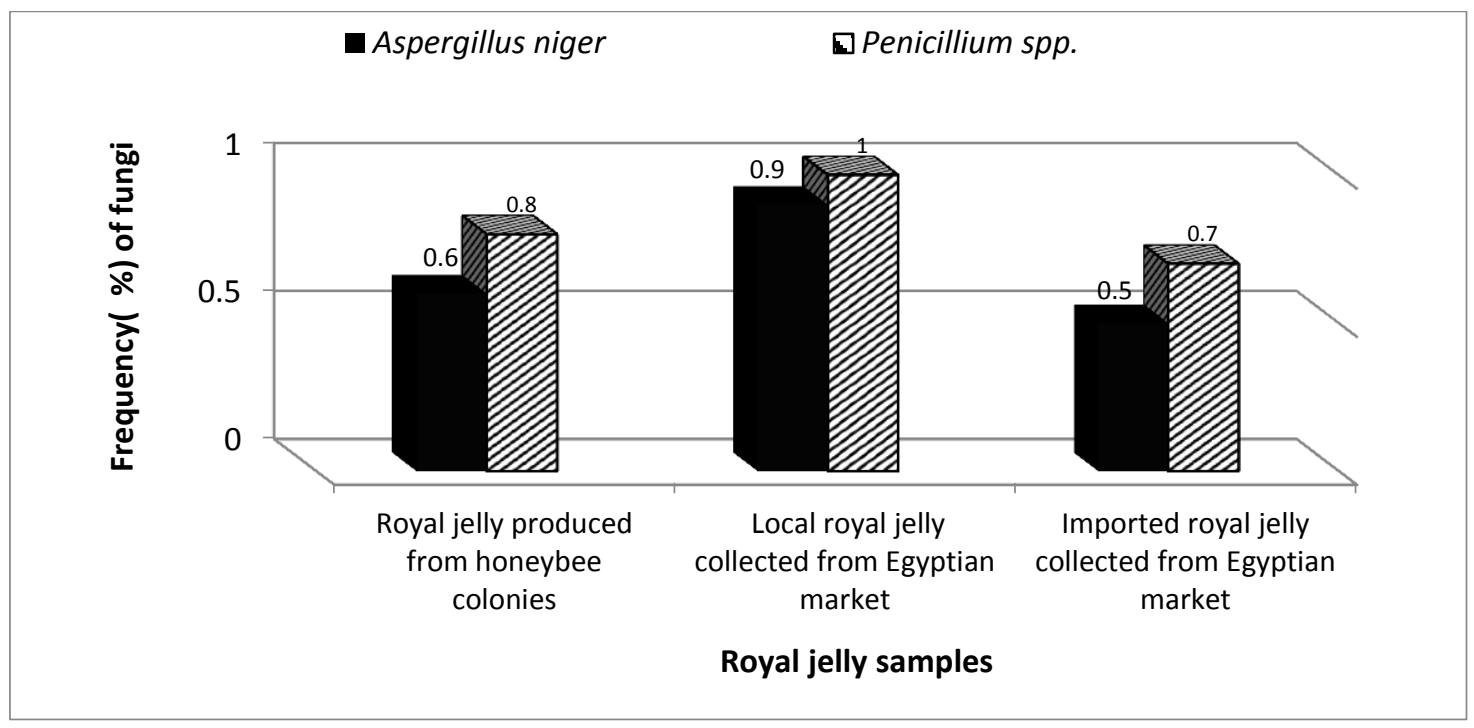

Fig. 3. Frequency (\%) of fungi in royal jelly samples produced from honeybee colonies, local royal jelly samples collected from Egyptian market and imported royal jelly samples collected from Egyptian market. 


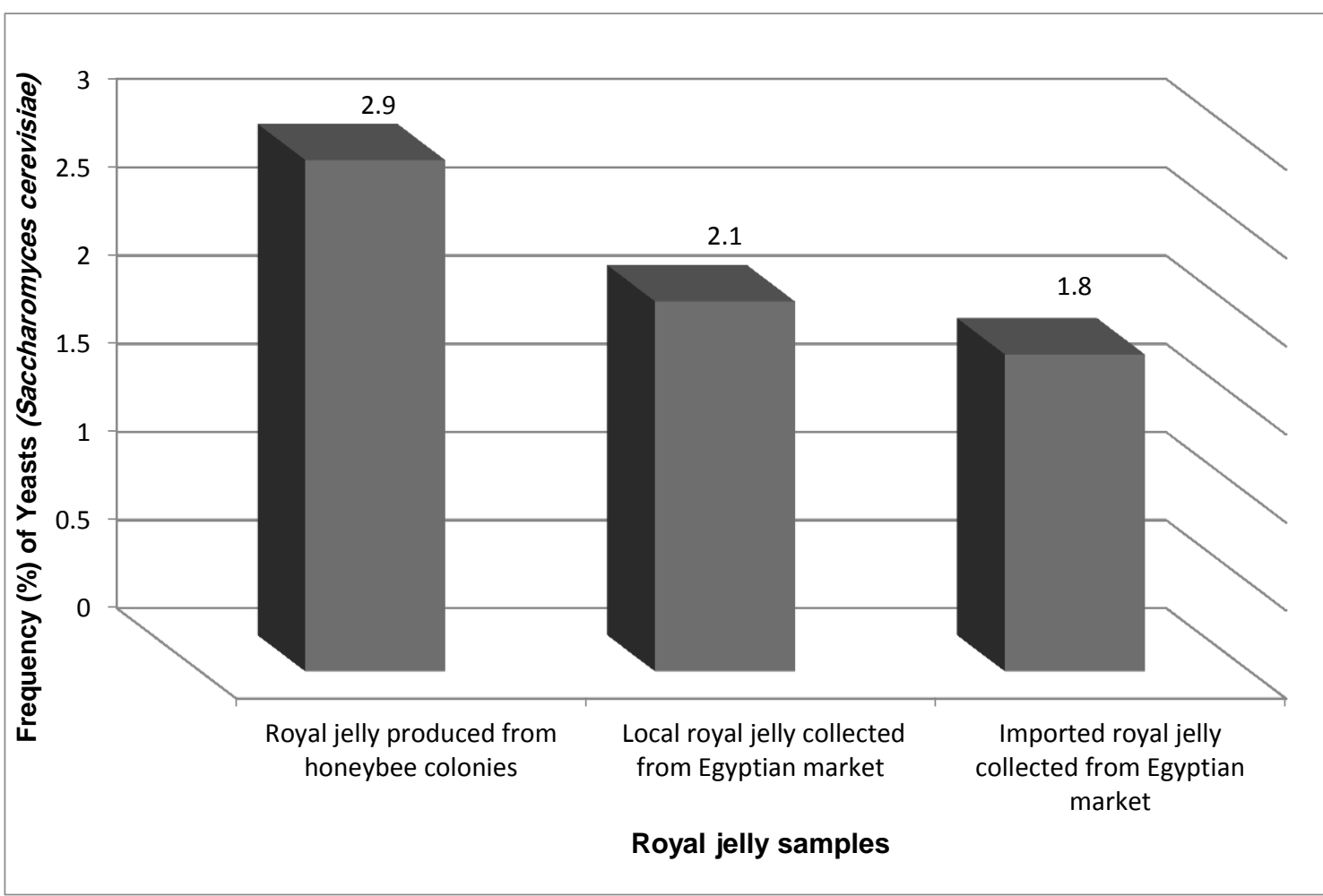

Fig. 4. Frequency (\%) of yeasts in royal jelly samples produced from honeybee colonies, local royal jelly samples collected from Egyptian market and imported royal jelly samples collected from Egyptian market

The water soluble extracts of pure royal jelly exhibited antibacterial effect against Staphylococcus aureus, Escherichia coli, Streptomyces griseus, and three unclassified strains of Streptomyces (Eshraghi and Seifollahi, 2003). The results given by Butenandt and Rembold, (1957) reported that royal jelly exhibited antibiotic activity against a variety some actinomycetes and certain species of fungi. It is obvious that the antibacterial of royal jelly differs significantly from that of apidaecins.

\section{REFERRENCES}

Barnett H.L. and Hunter B.B.1987. Illustrated Genera of imperfect Fungi. Burgress Co., Minneapolis, Minnesota, USA, 241 p.

Barnett J.A., Payne R.W. and Yarrow D. 2000. Yeasts characterization and identification. Cambridge University Press, Cambridge, UK, $351 \mathrm{p}$.

Bilikova K., Wu. G. and Imuth J.S. 2001. Isolation of a peptide fraction from honeybee royal jelly as a potential antifoulbrood factor. Apidologie, 32, 275-283.
Blum M.S., Novak A.F. and Taber S. Ill1959.10Hydroxy- $\Delta 2$-Decenoic Acid, an Antibiotic Found in Royal Jelly. Sci., 130, 452-453.

Bochner B.R. 1991. Identification of over 500 Gram-negative species by a single test panel. American Clinical Laboratory, 14 p.

Budavari S., O'Neil M.J., Smith A., Heckelman P.E. and Kinneary J.F. 1996. The Merck Index Published by Merck Research Laboratories division of Merck \& Co. INC. Whitehouse Station NJ. USA, $1425 \mathrm{p}$.

Butenandt A. and Rembold H. 1957. Royal jelly of the honeybee. I. Isolation, constitution analysis, and incidence of 10-hydroxy-delta 2decenoi acid. Z. Phys. Chem., 129, 285-308.

Eshraghi S. and Seifollahi F. 2003. Antibacterial Effects of Royal Jelly on Different Strains of Bacteria. Iranian J. Publ. Health, 32(1), 25-30.

Fahy A.C. and Persley G.T. 1983. Plant Bacteria Diseases; A Diagnostic Guide. Academic Press, New York, USA, 393 p.

Fontana R., Mendes M.A., Monson de Souza B., Konno K., L'ilian Mari Marcondes César, Malaspina O. and Palmab M.S. 2004. Jelleines: a family of antimicrobial peptides 
from the Royal Jelly of honeybees (Apismellifera). Peptides, 25, 919-928.

Fujii A., Kobayashi S., Kuboyama N., Furukawa Y., Kaneko Y., Ishihama S., Yamamoto H. and Tamura T. 1990. Augmentation of wound healing by royal jelly in streptozotocin Diabetic Rats. Japan J. Pharmacol, 53, 331-337.

Fujiwara S., Imai J., Fujiwara M., Yaeshima T., Kawashima T. and Kobayashit K.1990. A Potent Antibacterial Protein in Royal Jelly. Potent Antibacterial Protein in Royal Jelly, J. Biol. Chem. 265, 11333-11337.

Genc M. and Aslan A. 1999. Determination of trans-10-hydroxy-2-decenoic acid content in pure royal jelly and royal jelly products by column liquid chromatography. J. Chromatogr, A. 839, 265-268.

Kitahara T., Sato N., Ohya Y., Shinta H. and Hori K. 1995. The inhibitory effect of $\omega$-hydroxy acids in royal jelly extract on sebaceous gland lipogenesis. J. of Dermatol Sci., 10, 75-79.

Kreger-Van Rij N.I.W. 1984. The yeasts: A taxonomic study, 3rd Ed., Elsevier Science Publishers, Amsterdam, Nether land, $301 \mathrm{p}$.

Lees P. and Aliabadi F.S. 2002. Rational dosing of antimicrobial drugs: animals versus humans. International J. of Antimicrobial Agents, 19, 269-284.

Lercker G., Cappela P., Conte L.S., Ruini F. and Giordani G. 1982. Components of Royal Jelly II: the lipid fraction, hydrocarbons and sterols. J. Apicult Res., 21(3), 178-184.

Leung R., Ho. A., Chan J., Choy D. and Lai C.K. 1997. Royal jelly consumption and hypersensitivity in the community. ClinExp Allergy. 27, 333-336.

Lombardi C., Senna G.E., Gatti B., Feligioni M., Riva G.,Bonadonna P., Dama A.R., Canonica G.W. and Passalacqua G. 1998. Allergic reactions to honey and royal jelly and their relationship with sensitization to compositae. Allergol. Immunopathol Madr., 26, 288-290.

Manfredi R. and Chiodo F. 2000. The effects of alternative treatments for HIV disease on and recommended pharmacological regimens. Int. J. of Antimicrobial Agents. 13, 281-285.
McCleskey C.S. and Melampy R.M. 1938. Bactericidal activity of royal jelly of the honey Bee. J. Bacterial. 36, 324-327.

Mehrotra N.K., Sharma N., Ghosh R. and Nigam M. 1996. Biological control of green and mould disease of citrus fruit by yeasts. Indian Phytopathol. 49, 350-354.

Odds F.C. 1988. Candida and Candidosis, $2^{\text {nd }}$ Ed., Bailliere Tindall, London, UK, 189 p.

Oka H., Emori Y., Kobayashi N., Hayashi Y. and Nomoto K. 2001. Suppression of allergic reactions by royal jelly in association with the restoration of macrophage function and the improvement of Th1/Th2 cell responses. Int. Immunopharmacol. 1, 521-532.

Palma M.S. 1992. Composition of freshly harvested Brazilian Royal Jelly: identification of carbohydrates from the sugar fraction. J Apicult Res., 31(1), 42-44.

Parfitt K. 1999. Martindale. thirty second edition the complete drug reference published by the pharmaceutical press London SE1 7JN UK. Printed in the USA by Taunton Massachusetts, $1626 \mathrm{p}$.

Schaad N.W. 1980. Laboratory guide for identification of plant pathogenic bacteria. The American Psychopathological Society, St. Paul, Minnesota, USA, $72 \mathrm{p}$.

Shen X., Lu R. and He G. 1995. Effects of lyophilized royal jelly on experimental hyperlipidemia and thrombosis. hung Hua Yu Fang I Hsueh TsaChih, 29, 27-29.

Sndecor G.W. and Cocheran W.G. 1990. Statistical Methods, $7^{\text {th }}$ Ed., lowa State Univ., Press, Ames, lowa, USA, $507 \mathrm{p}$.

Takahashi K. Koshino H., Esumi Y., Tsuda E. and Kurosawa K. 2001. SW-163C and E, novel antitumor depsipeptides produced by Streptomyces sp. II. Structure elucidation. J. Antibiot. 54, 622-627.

Vittek J. 1995. Effect of royal jelly on serum lipids in experimental animals and humans with atherosclerosis. Experientia, 51, 927-935.

Weston R.J., Brocklebank L.K. and Lu Y. 2000. Identification and quantitative levels of antibacterial components of some New Zealand honeys. Food Chemistry, 70, 427-35. 


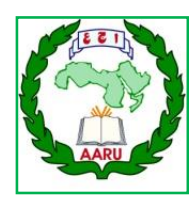

مجلة اتحاد الجامعات العربية للعلوم الزراعية ، جامعة عين شمس ، القاهرة ، مصر

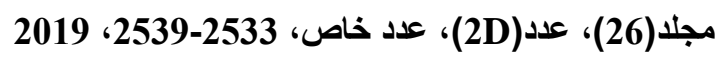

Website: http://strategy-plan.asu.edu.eg/AUJASCI/

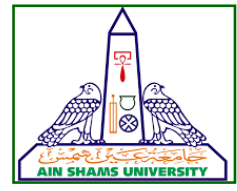

2539

أكنائنات الحية الاقيقة ( البكتريا والفطريات والخميرة) فى غذاء ملكات النحل

[187]

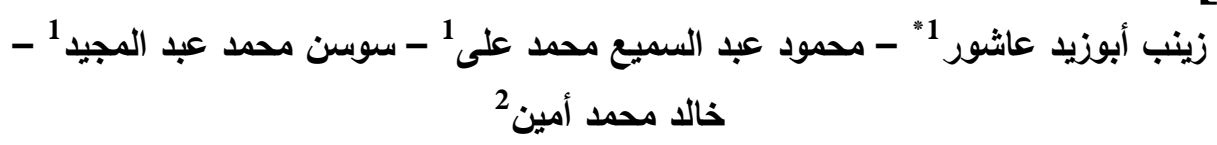

1- قسم وقاية النبات - كلية الزراعة -جامعة عين شمس- ص.ب 68-حدائق شبرا 11241 - القاهرة- مصر

2- قسم الكيمياء الحيوية- كلية الزراعة -جامعة عين شمس - ص.بـ88-حدائق شبرا

*Corresponding author: zozomoon1991@yahoo.com

Received 29 July, 2018, Accepted 30 September, 2018

المزرعة التي نم عزلها. وخلصت النتائج الى ان بكتريا Clostridium botulinum كانت الأكثر تكراراً مقارنة التهان بأنواع البكتيريا الأخرى، حيث كانت النسبة المئوية

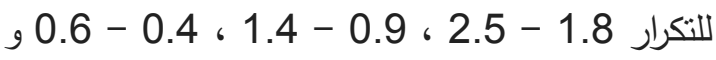
،C. botulinum بكتريا 2.0 - 1.5 Micrococcus , B. wakoensis ،B.cereus

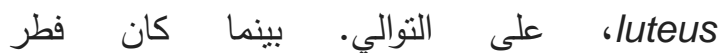
A. هenicilliumsp niger - 1.0 \% على التوالى، في عينات غذاء ملكات النحل

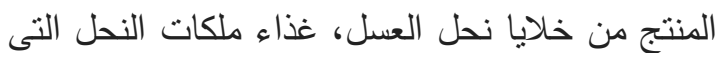
تم جمعها من السوق المصري وعينات غذاء الماء الملكات

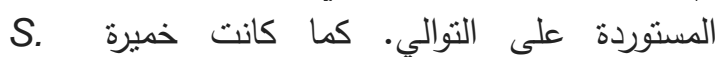
Cerevisiae المنتجة من خلايا النحل (2.9 \%) تلاها غذاء ملكاء ملكات

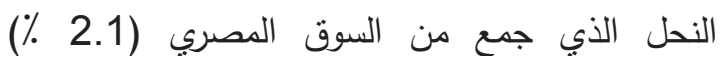
وعينات غذاء الملكات المستوردة (1.8 \%).

الكلمات الدالة: غذاء ملكات النحل، الكائنات الحية الدقيقة، بكتريا، خمائر ، فطريات

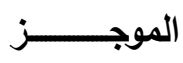

الهدف من الدراسة الحالية الكثف عن أعداد

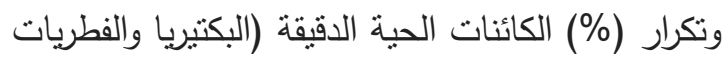

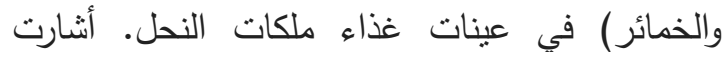

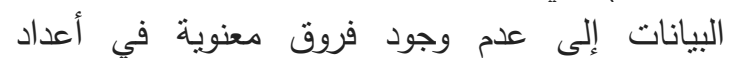
الكائنات الحية الدقيقة بين جميع العينات للبكتيريا والفطريات والخمائر ، حيث كان المتوسط العام للتعداد (5.923، 1.38 و 7.85 مستعمره / عينة) البكتيريا

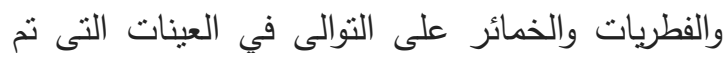

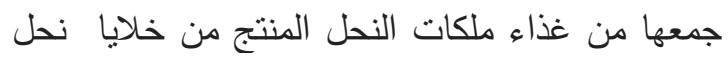

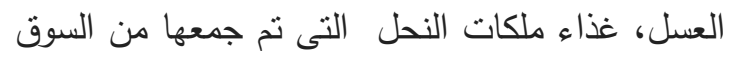

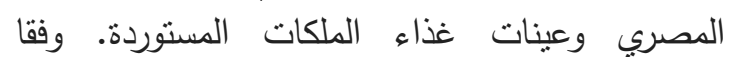
لإجراءات العزل والتعريف للكائنات الحية الدقيقة في العيات

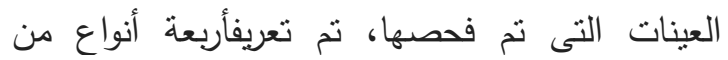

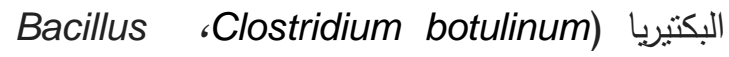
9 Bacillus wakoensis ‘cereus (Micrococcus luteus ونوع (.Penicilliumsp و دن Aspergillusniger) خميرة واحد (Saccharomyces cerevisiae)، حيث نم تعريفها وفقا للصفات وخصائص وفسيولوجيا 
